\title{
19-Barthes'ın Sarrasine (S/Z) okuması ile Sâmipaşazâde Sezâi'nin Bu Büyük Adam Kimdir? hikâyesinde hermenötik kod sorunu
}

\section{Atiye Gülfer GÜNDOĞDU1}

APA: Gündoğdu, A. G. (2020). Barthes’nn Sarrasine (S/Z) okuması ile Sâmipaşazâde Sezâi’nin Bu Büyük Adam Kimdir? hikâyesinde hermenötik kod sorunu RumeliDE Dil ve Edebiyat Araştırmaları Dergisi, (Ö8), 248-261. DOI: 10.29000/rumelide.824562.

\section{$\ddot{O} \mathbf{z}$}

Balzac'ın Sarrasine adlı metninin gösterilenlerine ulaşacak olan beş büyük kodu çözdüğünü iddia ettiği yapısökümcü $S / Z$ okumasında Barthes'ın, metnin çoğulluğunu ortaya koymak için başvurduğu kodlardan birisi de hermenötik koddur. Buna göre hermenötik kod, edebî metnin muhtevasıyla ilgili olarak odağına bir muammanın (enigma) yerleştirildiği, geciktirildiği ve nihayetinde çözümlendiği okuma düzlemi olarak tanımlanır. Burada dikkat çeken Barthes'ın edebî metin okumasına dair bir çoğulluk oluşturma çabası içine girerken hermenötik kavramını metnin muhtevasında yer alan enigmayı açı̆̆a çıkaracak, çözecek netlikte bir kod olarak sınırlamasıdır. Türk edebiyatında, daha başlığından itibaren kendisini belli bir gizemle açan, çeşitli aldatmacalarla ilerleyen ve başlı̆̆ındaki gizem nihayetinde çözülen metinlerden birisi Sâmipaşazâde Sezâi’nin $B u$ Büyük Adam Kimdir? adlı hikâyesidir. Sarrasine'de La Zambinella'nın cinsiyetinin aslında ne olduğu muammasının "kadın rolünün o dönemde kadınlar tarafından sahnelenmeyişi gerçeğiyle çözülmesi gibi (La Zambinella, Zambinella’ya dönüşür, üstelik hadım edilmiştir), Bu Büyük Adam Kimdir?'de de metin boyunca büyük bir adam olduğu öngörülen (bir "Victor Hugo mu? yoksa Jean Jacques Rousseau mu?” olduğu düşünülen) kişinin okumasını yazmasını dahi bilmeyen bir câhil olduğu (büyük adam, okumasını yazmasını bilmeyen bir adama dönüşür) açığa çıkar. Bu çalışmada bir taraftan hermenötik kod düzleminde gerçekleştirilen okumaların, edebî metinlerin özgünlüğünü yitirmesine etki edip etmediği sorusu etrafında Sâmipaşazâde Sezâi'nin Bu Büyük Adam Kimdir? adlı hikâyesi Sarrasine ile birlikte okunmaya çalışılacaktır. Bir taraftansa edebî metinlerin yorumlanmasında gerek hermenötiğin gerekse onunla ilişkili olarak muamma (enigma) kavramının hermenötik kod içerisinde kendisine biçilen sınırlarının dışına taşan anlam dünyasına temas edilerek Barthes'ın S/Z'de öne çıkan çoğulluk oluşturma çabasına ve çağrısına farklı bir açıdan katkıda bulunulmaya çalışılacaktır.

Anahtar kelimeler: Barthes, S/Z, Bu Büyük Adam Kimdir?, hermenötik kod, muamma

\section{Hermeneutic code problem in Barthes's reading of Sarrasine $(S / Z)$ and Samipaşazâde Sezâi's story of Who Is This Great Man?}

\begin{abstract}
One of the codes used by Barthes to reveal the plurality of the literary text in his $S / Z$, a deconstructive reading of Balzac's Sarrasine, was the hermeneutic code. Accordingly, it is assumed that there is a enigma in the text, and this enigma is tried to be solved by hermeneutic code. What stands out here is that Barthes describes the meaning of the hermeneutic concept as a code that will solve the enigma of the text as he strives to create a plurality in reading literary texts. In this
\end{abstract}

Dr. Öğr. Üyesi, Ondokuz Mayıs Üniversitesi, Fen-Edebiyat Fakültesi, Türk Dili ve Edebiyatı Bölümü (Samsun, Türkiye), atiyegulfer.kaymak@gmail.com, ORCID ID: 00oo-0002-7606-4292 [Makale kaylt tarihi: 12.09.2020-kabul tarihi: 20.11.2020; DOI: 10.29000/rumelide.824562] 
respect, one of the texts in Turkish literature based on an enigma from its title to the last sentence is Samipaşazâde Sezâi's story of "Who is This Great Man?". Just as the enigma of what is the gender of La Zambinella actually in Sarrasine is resolved by the fact that the female role was not performed by women at that time (La Zambinella turns into Zambinella, moreover, he was castrated), in Who is This Great Man?, it is revealed that the person who is supposed to be a great man throughout the text (thought to be a Victor Hugo or a Jean Jacques Rousseau) is ignorant who does not even know how to read and write (the great man turns into an illiterate man). In this paper, first of all, a comparative reading will be made between Samipaşazâde Sezâi's story of "Who is This Great Man?" and Sarrasine around the question of whether the readings performed in the hermeneutic code axis serve to lose the originality of literary texts. Secondly, it will be contributed to Barthes' effort and invitation to create the plurality that stands out in $\mathrm{S} / \mathrm{Z}$ from a different perspective by touching the world of meaning that goes beyond the boundaries of both the hermeneutics and the concept of enigma (in relation to it) within the hermeneutic code in the interpretation of literary texts.

Keywords: Barthes, $S / Z$, Who Is This Great Man?, hermeneutic code, enigma

\section{Giriş}

Barthes'in, Balzac'ın Sarrasine adlı hikâyesi üzerine yaptığı ünlü $S / Z$ okumasının (1970/2006) edebî metin yorumlamaları arasında özel bir yer edinmesini² sağlayan şey temelde, edebî metne belli bir anlam kazandırmaktan ziyade onun hangi çoğuldan oluştuğunu saptama teşebbüsü olmasıdır. "Bir betiği yorumlamak; ona (...) bir anlam kazandırmak değildir, tersine onun hangi çoğuldan oluştuğunu saptamaktır" (Barthes, 2006: 17). Çalışmaya dikkat çeken bir diğer husus, sahip olduğu bu iddia ile $S / Z$ nin, Barthes'ın eleştiri pratiğinde önemli bir kırılmayı gerçekleştirerek yapısalcılıktan postyapısalcılığa geçiş projesi olarak görülmesidir. Söz gelimi Eagleton bu süreci, Barthes'in ünlü yazısına atıfla "eserden metne" (Barthes, 1977: 155-164) geçiş süreci olarak ele alır ve detaylandırır: "Roman veya şiiri eleştirmenin şifresini çözmekle görevli olduğu belirli anlamlarla donanmış kapalı bir kendilik olarak görmekten, indirgenemeyecek biçimde çoğul bir şey olarak, sonuçta hiçbir zaman tek bir merkeze, öze ve anlama indirgenemeyen gösterenlerin sonsuz bir oyunu olarak görmeye geçiş" (Eagleton, 2011: 149). Diğer taraftan Culler, $S / Z$ de yapısalcılıktan post-yapısalcılığa doğru önemli bir değişimden geçmesinin Barthes'ın bizatihi kendisinin beslediği bir düşünce oluşuna dikkat çeker. Zira $S / Z$ de üzerinde durulan konular Barthes'ın önceki eserlerinde ele almadığı hususlar değildir (Culler, 2008: 102). Benzer şekilde Palmer da $S / Z$ yi bir metne yapısalcı bir yaklaşımla neler yapılabileceğinin erken bir izi olarak değerlendirir (Palmer, 1983: 55). Nihayetinde $S / Z$, hakkında oluşan bu farklı kanaatleri, edebî metinlerin yorumlanmasına dair bir çoğulluk oluşturma vurgusu etrafinda canlı tutmayı başarır. Metnin derin yapısını değil de çoğulluğunu ortaya çıkarma amacını açıkça çalışmasının merkezine yerleştirir. "Her sözbirim için düzenli bir biçimde bu gösterilenleri ortaya çıkarmanın amacı, betiğin gerçekliğini (düzenini sağlayan derin yapısını) değil de onun (pinti de olsa) çoğulluğunu ortaya çıkarmaktır” (Barthes, 2006:24). Bu amacını Balzac'ın Sarrasine adlı metnini küçük okuma birimine bölerek ve beş ayrı kod eşliğinde beş farklı düzlemde uyguladı̆̆ı okuma üzerinden gerçekleştirir. 561 okuma birimine bölünerek beş farklı kod etrafında gerçekleştirilen bu okuma -Barthes'a göre, kelimenin Nietzscheci anlamıyla yorumlama işlemidir bu- (2006: 17) adım adım, ağır çekim şeklinde gerçekleştirilir, metni gereğinden fazla yapılaştırmaktan kaçar, onu kapatacak bilimsel yazılardan kaçınır, onu derleyip toplamak yerine yıldızlarla donatır (2006: 23). Burada yldızlarla donatma ifadesinin, edebî metnin üretici bir okurunun yorumlama gücüyle

Peggy Rosenthal, S/Z'nin yazıldığı dönemde oluşturduğu etkinin altını çizmek için, onaylanmadığında bile genellikle "parlltılı" bir okuma olarak görüldüğüne dikkat çeker (Rosenthal, 1975: 125).

Adres

Osmanağa Mahallesi, Mürver Çiçeği Sokak, No: 14/8 Kadıköy / Istanbul / TÜRKIYE

e-posta: editor@rumelide.com

+90 (505) 7958124 / +90 (216) 7730616
Address

Osmanağa Mahallesi, Mürver Çiçeği Sokak, No: 14/8

Kadıköy / Istanbul / TURKEY

e-mail: editor@rumelide.com

+90 (505) 7958124 / +90 (216) 7730616 
Barthes'ın Sarrasine (S/Z) okuması ile Sâmipaşazâde Sezâi’nin Bu Büyük Adam Kimdir? hikâyesinde hermenötik kod sorunu / A. G. Gündoğdu(pp. 248-261)

parıldayışı, yıldızın ışığının beş ayrı kod şeklinde saçaklanışı, dağılışı, böylece bu parıldayış, saçaklanış içinde metnin kapalı bir yapı içine hapsedilişinin reddedilişi gibi anlamlara işaret ettiği düşünülebilir. Ayrıca Sarrasine, ( $S / Z$ okumasının orijinal dilinde ve İngilizce çevirisinde yer aldığı üzere) beş ayrı kod etrafında cümle cümle analiz edilirken, okuma birimleri içinde yer tipografik işaretler eşliğinde de yldizlarla donatılır.

$\mathrm{Bu}$ noktada, gerek tipografik işaretlerle ve gerekse mecazi anlamda saçaklanan bir yıldızlı okuma olarak $S / Z$ nin sahip olduğu bu çoğulluk oluşturma iddiasının³, Barthes'ın yarattığı teknik kavramlarla uygunluk gösterip göstermediği üzerinde durulmaya değer bir mesele haline gelir. Zira her bir kod, $S / Z$ nin bu iddiasını açı̆̆a çıkarmasında göstereceği hassasiyet açısından ayrı bir öneme sahiptir. Gerçekten bu beş kod, metnin derin yapısını değil de onun çoğulluğunu ortaya çıkarmayı mı amaç edinir? Bu sorun etrafında Barthes'ın oluşturduğu beş teknik koda ve onları anlamlandırma biçimlerine bakıldığında içlerinden en fazla dikkat çekenin hermenötik kod olduğu söylenebilir. Böyle bir dikkatin oluşmasında, hermenötiğin anlama ve yorumlama tarihinde Barthes'ın kendisine biçtiği sınırların dışına taşan geniş bir anlam dünyasına sahip olarak, bu kod içinde yüklendiği sınırlı anlamla, $S / Z$ nin edebî metinler etrafında çoğulluk oluşturma iddiasıyla sorunlu bir ilişki yaşaması etkili olmuştur. Yine hermenötik kodun etrafında örüldüğü, doğuşundan itibaren felsefenin en köklü kavramları arasında yer alan muamma (enigma) da bu kod içerisinde çoğulluğu budanan bir diğer kavram olarak benzer bir dikkatin oluşmasına katkıda bulunur. Hermenötik kod içinde bu kavram, aşılamayan, geride bırakılamayan bir muammadan ziyade şifresi çözülerek dekode edilebilen bir kod, kendisine ulaşılabilen bir anlam olarak yer alır. Bu haliyle hermenötik kod içinde muamma, edebî metnin çoğulluğunu ortaya çıkaran bir nihai anlama ulaşılamazlık olarak değil de onun derin yapısını açığa çıkaran bir enigma olarak konumlandırılır. Kodların becerikli şifre kırıcısı Barthes yapısalcı eleştiri pratiğinden gelen alışkanlıkla onu, edebî metinlerin çoğulluğunu sağlayan bir kavram olarak ele almaktan ziyade metnin derin yapısını, anlamını açığa çıkarılabilecek bir kesinlik haline büründürür. Oysaki muamma (enigma) kavramı, anlamsal dünyası itibarıyla belli bir çoğulluğun, çok anlamlılığın oluşmasına katkı sağlayacak tabiata fazlasıyla sahiptir.

Bu yazıda Barthes'ın daha ziyade klasik hermenötiğin anlam alanı üzerine inşa ettiği hermenötik kod kavramını, hermenötiğin klasik sonrasında yaşamış olduğu kritik tarihsel dönüşümü göz ardı ederek tek bir boyutuyla oluşturmuş olduğu iddia edilecektir. Gerek hermenötiğin gerekse onunla ilişkili olarak muamma (enigma) kavramının hermenötik kod içerisinde kendisine biçilen sınırlarının dışına taşan anlam dünyasına temas edilerek Barthes'ın $S / Z$ de öne çıkan çoğulluk oluşturma çabasına ve çağrısına farklı bir açıdan katkıda bulunulmaya çalışılacaktır. Edebî metinlerinin çoğulluğunu ortaya çlkarmaya çalışırken bunu tesis etmek için oluşturulan kavramların tarihsel dönüşümlere uğramış çoğul anlam dünyasını göz önünde bulundurmak da önemlidir. Edebî metinler kadar kavramların çoğulluğunun budanması da tehlikelidir.

Yazının sorunsallaştırdığı bu meseleler üzerinde dururken, hermenötik kodun edebî metin okumalarımızı nasıl etkilediği ve yönlendirdiği üzerine bir karşılaştırma yapmak bizlere önemli

3 Çoğulluk oluşturma iddiasının Barthes'ın okuma ve yorumlama üzerine yaptı̆̆ pek çok analize, kavram ve alt başlıklandırmaya (yıldızlı betik, kaç okuma? gibi) yansıdığı görülür. $S / Z$ de çoğul okuma ve yorumlama üzerine yapılan analizlerin dikkat çekici ikisini şöyle sıralamak mümkündür: "Metin, bütünlüğü içinde, hem düz hem derin, kaygan, kıyısız ve göstergesiz bir gökyüzüne benzetilebilir; bazı ilkelere göre kuşların uçuşunu yorumlamak için sopasının ucuyla gökyüzünden düssel bir dikdörtgen çizen bir müneccim gibi yorumcu da anlamların göçünü, düzgülerin yan yana gelişlerini, alıntıların geçişini gözlemlemek için metin boyunca okuma kuşakları çizer.” (Barthes, 2006: 24). "(i)deal metinde, ağlar çok sayıdadır ve hiçbiri ötekinin üstünde olmaksızın, kendi aralarında işlerler; bu metin gösterilenlerden olusmus bir yapı değil de gösterenden olussmuş bir galaksidir; başlangıcı yoktur" (2006: 17). Bu analizlerin ortak yanı, edebî bir metni okuma tecrübesinin yer yüzünden ziyade sonsuzluğu daha ziyade çağrıştıran göğe ilişkin metaforlar eşliğinde (kıyısız ve göstergesiz bir gökyüzü, başlangıcı olmayan bir galaksi) ele alınıyor olmasıdır.

Adres

Osmanağa Mahallesi, Mürver Çiçeği Sokak, No: 14/8 Kadıköy / Istanbul / TÜRKIYE

e-posta: editor@rumelide.com

+90 (505) 7958124 / +90 (216) 7730616
Address

Osmanağa District, Mürver Çiçeği Street, No: 14/8

Kadıköy / Istanbul / TURKEY

e-mail: editor@rumelide.com

+90 (505) $7958124 /$ +90 (216) 7730616 
katkılar sunacaktır. Bu bağlamda yapacağımız karşılaştırma Barthes'ın $S / Z$ okuması ile Sâmipaşazâde Sezâi'nin Bu Büyük Adam Kimdir? adlı eseri arasında olacaktır. Bu karşlaştırmada şu soruların izi sürülecektir: Hermenötik kod bizi nasıl bir okuma tecrübesinin içerisine iter? Bize benzersiz bir okuma tecrübesi mi sunar, benzer bir süreç içinde ilerlemek durumunda kalan bir okuma güzergahı mı çizer? $\mathrm{Bu}$ anlamda edebî metinlerin farklılı̆̆ını yitirmesine mi hizmet eder, yoksa edebî metinlerin çoğulluğunu ortaya çıkarmaya mı?

\title{
1. Hermenötik kod üzerine bir karşılaştırma: Sarrasine ve Bu Büyük Adam Kimdir?
}

Balzac'ın Sarrasine adlı metninin gösterilenlerine ulaşacak olan beş büyük kodu çözdüğünü iddia ettiği yapısökümcü $S / Z$ okumasında Barthes'ın, metnin çoğulluğunu ortaya koymak için başvurduğu kodlardan birisi de hermenötik koddur. (Hermenötik kod, Türkçe'ye çevirmenince yorumbilgisel düzgü şeklinde çevrilmiştir.) Buna göre hermenötik kod, edebî metnin muhtevasıyla ilgili olarak odağına bir muammanın (enigma) yerleştirildiği, geciktirildiği ve nihayetinde çözümlendiği okuma düzlemi olarak tanımlanır.

$S \mid Z$ de Gerçeğin Sesini (Barthes, 2006: 30) seslettiğini ifade ettiği hermenötik kod ile tam olarak neyi kastettiği ile ilgili olarak şunları söyler Barthes:

\begin{abstract}
İşlevi, bir soruyu, onun yanıtını veya soruyu hazırlayabilecek ya da yanıtı geciktirebilecek çeşitli olayları, değişik biçimlerde, eklemlemek, hatta bir bilmece oluşturmak ve çözümünü getirmek olan birimlerin tümünü yorumbilgisel düzgü olarak adlandırmayı kararlaştıralım (bunu da yalınlaştırıp dizelgemizde YOR olarak belirtelim.) (2006: 26).

Yorumbilgisel düzgünün dökümü farklı (biçimsel) terimleri birbirinden ayırmaktan oluşacaktır, bu terimlere uyarak odağa bir bilmece yerleşir, varlığını ortaya koyar, oluşur, sonra da gecikir ve en sonunda çözümlenir (2006: 28).
\end{abstract}

Görüldüğü gibi Barthes, hermenötik kodun, odağa yerleştirilen ve çeşitli gecikmeler içerse dahi nihayetinde açıklığa kavuşacak olan muammaların, gizemlerin çözümünü sağlayacak ayrıntıları görmemize, tanımamıza ve düzenlememize yardımcı olacağını söyler. Ardından Sarrasine'de ortaya atılan, açıklanması için çeşitli geciktirimler yaşayan ve nihayetinde birbirine bağlantılı bir biçimde açıklı̆a kavuşan üç bilmecenin hermenötik kod ile çözülüşü üzerine adım adım, ağır çekim bir okuma gerçekleştirir. Ortaya konulan bilmeceler şunlardır:

1. Gizemli Lanty ailesinin varsıllığı, yani kökenleri nereden gelir ve servetlerinin kaynağı nedir?

2. Kontes Lanty’in düzenlediği eğlencelerde, konserlerde, balolarda, şenliklerde görülen garip kişilik kimdir?

3. Sarrasine adındaki Fransız yontu sanatçısının tutkuyla âşık olduğu İtalyan tiyatrocu, müzisyen La Zambinella'nun cinsiyeti nedir?

Bu üç bilmeceden ilk ikisinin cevabı üçüncü bilmecenin açığa kavuşmasıyla aydınlanmış olduğundan metinde en fazla üzerinde durulan bilmece üçüncüsü olur. Burada İtalyan tiyatrocu, müzisyen La Zambinella'nın cinsiyeti sorunu ortaya atılmış, zaman zaman söylemden okura, zaman zaman Sarrasine'nin kendisine yaptığı, zaman zamansa başka türlü gerçekleştirilen çeşitli aldatmacalarla bu cinsiyet sorunu askıya alınmış, ancak nihayetinde örtmeceli bir biçimde de olsa aydınlığa kavuşmuştur. Bununla ilişkili olarak diğer iki sorunun cevabı da ortaya çıar. Gizemli Lanty ailesinin varlığı, Kontes Lanty’in düzenlediği eğlencelerde, konserlerde, balolarda, şenliklerde görülen garip

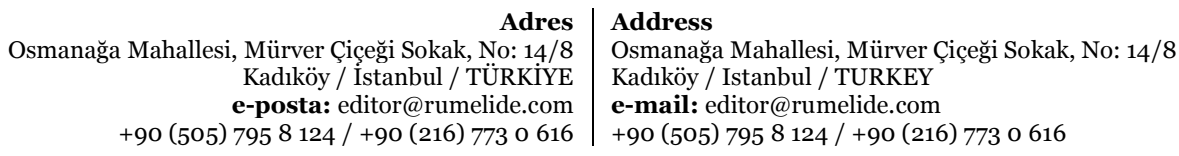


kişilik, Fransız yontu sanatçısının tutkuyla âşık olduğu İtalyan tiyatrocu, müzisyen ve hadım olan La Zambinella ile akrabalık ilişkisinden ileri gelir. Barthes'ın üçüncü bilmece hakkında hermenötik kod etrafında yaptı̆̆ı kritik analizler, yıldızlı okumalar kabaca şöyledir:

(417) -Ya bir kadın olmasaydım? *YOR. 6. Bilmece: gerçeğin açıklanması, La Zambinella'dan Sarrasine'e (147).

(418) Diye sordu La Zambinella ürkekçe, billur ve tatlı bir sesle (YOR. 6. Bilmece: aldatmaca, La Zambinella'dan Sarrasine'e) (147).

(419) -Dalga mı geçiyorsun! diye haykırdı Sarrasine. Bir sanatçının gözünü yanıltabileceğini mi sanıyorsun? ***YR. 6. Bilmece: aldatmaca, Sarrasine'den kendisine: güzelduyusal kanıt: sanatçılar yanılgıya düşmezler (147).

(420) On günden beri, kusursuz hatlarını içime alırcasına seyretmedim mi ben, dikkatle, hayranlıkla bakıp incelemedim mi!

(421) Yalnızca bir kadın bu yuvarlak ve yumuşak kola, bu güzelim hatlara sahip olabilir. (YOR.6. Bilmece: aldatmaca, Sarrasine'den kendisine) (148-149).

(422) Ah! Övgüler düzmemi istiyorsun. *YOR. 6. Bilmece: aldatmaca, Sarrasine'den kendisine (ruhbilimsel kanıt: cilvelilik) (149).

(432) Sanatçı sevdiğinin inmesine yardım etmek üzere kollarını uzattığında (...)

\section{(433) Onun tir tir titrediğini hissetti.}

-Neyiniz var? Bilmeden de olsa nedeni olduğum en küçük bir acınız bile varsa bu beni öldürürdü, diye haykırdı onun yüzünün solduğunu görünce.

-Bir yılan! dedi bir çukurun yanında sürünen bir karayılanı göstererek. Bu iğrenç hayvanlardan korkuyorum.

Sarrasine bir ayak darbesiyle karayılanın başını ezdi (151).

(434) -Nasıl bu kadar yürekli olabiliyorsunuz? dedi La Zambinella, gözden kaçmayan bir ürküyle ölü sürüngene bakarak.

(435)-Gördünüz mü, dedi sanatçı gülümseyerek, bir de kadın olmadığınızı ileri sürmeye cüret etmez misiniz? (YOR.6. Bilmece: aldatmaca, Sarrasine'den kendisine: kadınlığın ruhbilimsel kanit1) (152).

Zambinella daha sonra elçinin konağında verilen yemeğe şarkı söylemesi için davet edilir. Bu yemeğe Zambinella'yı görmek hatta sonrasında arkadaşlarının yardımıyla onu kaçırmak arzusuyla Sarrasine de katılır. Zambinella şarkı söylediği anda salona ulaşan yontucu Sarrasine, Zambinella’yı erkek kılı̆̆ında gördüğünde yanındaki derebeyine şu soruyu yöneltir:

(466) -Kuşkusuz buradaki Kardinallere, Piskoposlara ve Rahiplere saygı gereği olmalı ki bu kadın erkek kılığında giyinmiş, başının arkasında bir kese ve yan tarafında bir kılıç

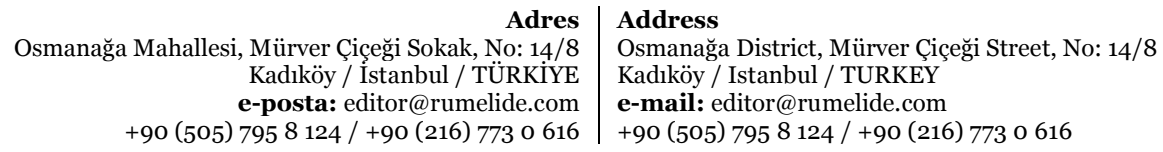


var, bir de saçları kabartılmış? (YOR.6. Bilmece: aldatmaca, Sarrasine'den kendisine) (160). "Kabartılmış saçlar": bu ayrıntı gerçekçidir, belirgin olduğu şey konusunda değil de Napolili bir ragazzonun imgesini açığa vurduğu, ve, hadımların tarihsel düzgüsüne uygun bu imge oğlanın açı̆̆a vurulmasına, bilmecenin çözümüne kılıçtan ya da giysiden daha keskin bir biçimde katkıda bulunur (YOR. 6. Bilmece: çözüm, ve GÖN. Hadım edilmişlerin tarihsel düzgüsü).

(467)-Kadın mı! Kadın kim! diye yanıtladı Sarrasine’in sorusunu kendisine yöneltmiş olduğu yaşlı derebeyi.

-La Zambinella.

-La Zambinella mı! diye başladı yeniden Romalı Prens. Dalga mı geçiyorsunuz? *YOR.6.Bilmece: gerçeğin ortaya çıkarılması, topluluktan Sarrasine'e.

(468) Nereden geliyorsunuz siz? (YOR.6.Bilmece: gerçeğin ortaya çlkması: aldatmacanın dolaysız açılklanması) (161).

(469) Roma tiyatrolarına hiç kadın çıktı mı bugüne değin? Papanın egemen olduğu devletlerde kadın rollerinin hangi yaratıklar tarafından oynandığını bilmiyor musunuz siz? * YOR.6. Bilmece: gerçeğin ortaya çıkması (örtmeceli, genellemeyle kesinleşmiş ve sözcük söylenmemiș de olsa gerçek bundan daha iyi bir biçimde söylenmiș olamazdı: Zambinella bir hadımdır) (161).

Görüldüğü gibi La Zambinella'nın cinsiyetinin aslında ne olduğu sorunu La Zambinella'nın "Ya bir kadın olmasaydım?” sorusuyla başlamış, papanın egemen olduğu devletlerde kadın rolünün kadınlar tarafından sahnelenmeyişi gerçeğiyle sona ermiştir. Türk Edebiyatında, Balzac'ın Sarrasine’i gibi kendisini belli bir gizemle açan, çeşitli aldatmacalarla ilerleyen ve nihayetinde belli bir gerçekliğe kavuşan hikâyelerden biri, Sâmipaşazâde Sezâi’nin “Bu Büyük Adam Kimdir?” adlı metnidir. Gizemini daha başlığıyla birlikte ortaya koyan bu hikâyede bu büyük adamın kim olduğu sorunu, bazen insanın yüz ve vücut yapısı ile karakteri arasında bir bağ kuran ilm-i kıyâfet aracılığıyla anlatıcıdan kendisine, bazense söylemden okura uzanan çeşitli aldatmacalarla geciktirilmiş ve nihayetinde bu gerçeklik tütüncüden anlatıcıya aktarılan bir bilgiyle aydınlığa kavuşmuştur. Barthes'ın hermenötik koduyla Sâmipaşazâde Sezâi’nin "Bu Büyük Adam Kimdir" adlı metnine yaklaştığımızda karşımıza yaklaşık olarak şu tarzda çözümlemeler ${ }^{4}$ çıkacaktır:

Bu Büyük Adam Kimdir? (Sâmipaşazâde Sezâi, 1892/2016: 21) YOR. Bilmecenin ortaya konulması.

Bu mukannen olan [hiç şaşmadan yapılan] akşam azîmet ü avdetinde [gidiş dönüşlerinde] dâimâ bir adama tesâdüf ederdim ki kayıtsızlıktan [(kendi kendisiyle) ilgilenmemesinden (dolayı)] uzamış saçları geniş nâsiyesinin [alnının] üzerine dökülerek tefekkürât-ı amîka [derin düşünceler] içinde dalgın dalgın attığı adımlarıyla ikide birde sendeler ve düşmemek için hemen kendisini toplardı (21). YOR. Bilmece: aldatmaca anlatıcıdan kendisine, kıyafetbilimsel (ilm-i kıyafet) kanıt, ruhbilimselkanıt.

Söz konusu metin Barthes’ın "Sarrasine" okumasında olduğu üzere beş kod etrafında incelenmediği için küçük okuma birimlerine ayrılmamış ve tipografik olarak yıldızlarla donatılmamıştır. Bu yüzden cümlelerin başında ve sonunda herhangi bir numaralandırma ve yıldızlandırma yer almaz. Hikâyenin cümlelerinin bölünmesinde muammanın ortaya konması, geciktirilmesi, açığa çıkması vs. gibi hermenötik kod düzleminde gerçekleştirilen analizlere dair hususlar belirleyici olmuştur.

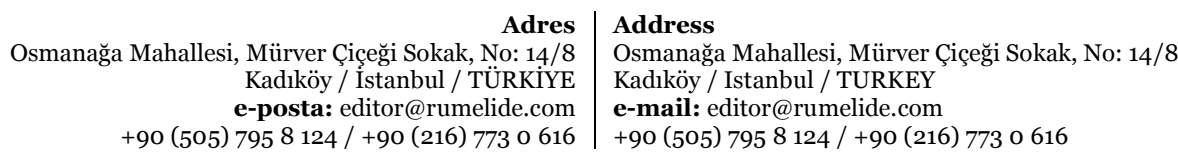


Bir kere kendi kendime "Bu büyük adam kimdir?" diye sordum. Bu zannım, bu suâlim sebepsiz değildi. Çünkü adamın her hâl ü tavrını [durum ve davranışını] o günlerde Fransız hocamızdan okuduğum, Büyük Adamlarm Hayat unvanlı [adlı] kitabın ta'rîfât ve tavsîfâtına [anlattıklarına ve betimlemelerine] anlattıklarına ve betimlemelerine tamamıle mutâbık [uygun] buluyordum. Ekseriyet üzere [çoğu zaman] Lâleli yokuşundan, istidlâlimce [anladığım kadarıyla] ya bir ihtirâ-i fennî [bilimsel buluş], ya bir bediâ-i edebî [yazınsal yapıt], ve'l-hâsıl [kısacası] bir maksad-ı âliye ma'tûf [yüce bir amaca yönelmiş] olan gözlerini göğe dikerek, o geniş nâsiye-i irfânı [kültürlü alnı] semâdan [gökyüzünden] aldığı bir ziyâ [1şık] ile münevver [aydınlanmış] göründüğü hâlde, Aksaray'a doğru inerdi (21). YOR. Bilmece: okunan kitaplara dair göndergesel aldatmaca anlatıcıdan kendisine, kıyafetbilimsel kanıt, ruhbilimselkanit.

İlm-i kıyâfetin ehemmiyeti [giyim biliminin önemi] inkâr olunamaz (21). YOR. Bilmece: aldatmaca anlatıcıdan kendisine, kıyafetbilimsel kanıt.

Bu büyük adamın gözleri câzibe-i kemâlât [yetkinliğin çekiciliği] ile o kadar illiyîn-i nazar [gökyüzünün en yüksek noktasına bakıyor] idi ki bir kere etrafındaki Koska'nın sütçü, tütüncü dükkânlarına, bir kere önündeki Aksaray'ın sokaklarına baktığını, başını döndürüp bir kimseye bir selam verdiğini görmedim. (22). YOR. Bilmece: aldatmaca anlatıcıdan kendisine, kıyafetbilimsel kanıt, ruhbilimselkanıt.

Victor Hugo mu, Jean Jacques Rousseau mu? Mesele burada.

Yavaş yavaş Jean Jacques Rousseau olduğuna hükmetmeye [karar vermeye] başladım. Zîrâ hiçbir adama selâm verdiğini, hiçbir adamla konuştuğunu görmediğim bu allâme-i merdüm-giriz [insanlardan kaçan bilgin], ekser [çoğunlukla] tramvay yolunun üstünden geçen çıngırakçı kömürcü develerinin arkasından ser-nümâ-yı hûşmendî olurdu [aklı başında bir tavırla başını çevirip bakardı]. (...) Belki o günlerdeki deve ta'kîbi itiyâdı [alışkanlığı], târîh-i tabiîye dâir [doğa tarihiyle ilgili] bir fikr-i tedkîk ve te'lîfe müstenid idi [bir inceleme (yapma) ve (bu konuda) yazma düşüncesine dayanıyordu]? (22-23). YOR. Bilmece: aldatmaca anlatıcıdan kendisine, hüsn-ü kuruntusal kanıt.

Etrâfındakilere: “Adam olmaz, insâniyet bilmez câhiller...Benim buradan geçtiğimi görmüyor musunuz? Gelip koluma dokunacak ne vardı? Meğer siz ne yaman câhiller imişsiniz?” diye feryâd ediyordu (23). YOR. Bilmece: aldatmaca söylemden okurlara.

Cehâletten şikâyet eden [bilgisizlikten yakınan] bu adam, kim bilir şimdi maârif ve terbiyeye dâir [bilgi ve eğitimle ilgili] ne büyük bir telif-i hikemî ile meşgûl olmaya [felsefe eseri yazmakla uğraşmaya] başlamıştır; niçin bu sokağın karanlığından bir şems-i ma'rifet tulû' etmesin [bilgi güneşi doğmasın]? Bu iştigâlât-ı mühimme âsâr ve esbabından [bu önemli uğraşın belirtisi ve nedenlerinden] olmak gerektir ki kendisine birçok zaman hiçbir yerde tesadüf edemedim (24). YOR. Bilmece: aldatmaca anlatıcıdan kendisine.

Eğer hâfızam beni yanıltmıyorsa, yirmi gün sonra tâ uzaktan, bir tütüncü dükkânında, tütüncünün kendisine okumakta olduğu bir kâğıdı kemâl-i itinâ [büyük bir özen] ve dikkat ile dinlediğini görerek o tarafa doğru gidince büyük adam da dükkândan 


\title{
çıkıordu. Tütüncüye(,) "Bu büyük adama okuduğu kâğıt ne idi?” diye sordum. Tütüncünün verdiği şu cevap, aradan seneler geçtiği hâlde, hâlâ hâtırımdan çıkmaz:
}

\author{
“ $O($,$) büyük adam değil, orta boylu. Memleketinden aldı̆̆ı mektupları her zaman bana$ \\ okutur. Onun okuması yazması yoktur." (24). YOR. Bilmece: Büyük adamın kim olduğunun, \\ gerçeğin ortaya çıkması, tütüncüden anlatıcıya. Anlatıcının büyük adamı sadece karakter olarak değil \\ fiziksel olarak da gözünde büyüttüğü gerçeğiyle karşılaşılır.
}

Nihayetinde metinde "Victor Hugo mu, Jean Jacques Rousseau mu?" (bir edebiyatçı yahut bilim insanı) olup olmadığı konusunda ikilemde kalınan bu büyük adamın, okumasını yazmasını dahi bilmeyen birisi olduğu gerçeğiyle karşılaşırız ve belki buradan Balzac'ın Sarrasine’i ile papanın otoritesinin tiyatro, mûsikî tarihine yansımasına doğru, Sezâi’nin “Bu Büyük Adam Kimdir?” adlı hikâyesiyle ise batılılaşmayı dış görünüşten ibaret olarak gören, gerçekliği yüzeyde arayan Tanzimat dönemi algılama sorununa yahut Tanzimat sonrası yükselen bilimselci düşünce karşısında insanın yüz ve vücut yapısı ile karakteri arasında bir bağ kuran ilm-i kıyâfete yöneltilen bir eleştiriye doğru yönelerek yorum alanımızı genişletebiliriz. Ancak neticede, hermenötik kod ile her iki metinde gerçekleştirilen şey, okurun metinle gerçekleştireceği karşılıklı söyleşi ile birlikte kendisini fark etmesi bağlamında kendi içinde yaşayabileceği gizem(li değişim) yerine metin içinde olay örgüsü bünyesinde yer alan, ortaya konan ve çözümlenmesi gereken bir gizemle ilgilenmek, bu gizemi çözecek ayrıntıları görmek, tanımak ve düzenlemek durumunda kalmasıdır. Bu hermenötik kod düzleminde, okurun metinle ilişkisinin onun muhtevası üzerine yoğunlaşarak ortaya konan ve çözümlenmesi gereken bir muamma ile ilgilenmek, bu gizemi çözecek ayrıntıları görmek, tanımak ve düzenlemek durumunda kalmasıly sınırlı olması anlamına gelir. Dahası bu durum okuru (Sarrasine ve Bu Büyük Adam Kimdir?'de olduğu üzere) kı-erkek, câhil-bilgin gibi ikili karşıtlıklar şeklinde düşünmeye yönlendirir. Her karşıt çift bir anlamda muamma oluşturacağından (Colli, 2007: 57) okurun okuma süreci, yapısal bir düşünme biçimi içinde şekillenmek durumunda kalır. Şüphe ilişkisi içinde metne yaklaşmak durumunda kalan okur, bu karşıt çiftlerin oluşturduğu muammalar arasında bir şekilde sınanmak ve bilginliğini ispatlamak sorumluluğunu yüklenir. $\mathrm{Bu}$ yönüyle okurlar metinle kurdukları ilişki bağlamında birbiriyle benzer güzergahları izleyecek bir okuma yolculuğuna çıkar. Chatman her ne kadar $S / Z$ okumasının "tek kullanımlık" (Chatman, 2008: 107) bir üsluba sahip olduğunu dile getirse de, çok kullanımlık hermenötik kod (çok sayıda edebî metne uygulanabilecek anlamında) içinde görülen şey, karşıt çiftlerin oluşturduğu muammalar arasında mutlak çözüme ulaşma noktasında benzer pozisyonlar içinde kalan okurun şahsına münhasır olmayan bir okuma tecrübesinin içine çekilmesidir. Onun bu çok sayıda edebî metne uygulanma ve okurunu benzer pozisyonlar içine sokan tutumunun, edebî metinlerin farklılığını yitirmesi tehlikesine kapı araladığını söylemek gerekir.

Netice itibariyle Barthes bir taraftan, beş farklı kod üzerinden gerçekleştirdiği $S / Z$ analizleri eşliğinde geleneksel bir metni, Balzac'ın "Sarrasine"ini benzersiz, eli yüzü tanınmaz bir şekle sokar.5 Bu durum yine Chatman'ın ifadesiyle söylenecek olunursa onun, anıtsal, parlak, delice bir yapıt olduğunun teslimidir (Chatman, 2008: 107). Ya da Eagleton'ın öne çıardığı gibi, Barthes'ın eleştirisinin metni yeniden yazan ve düzenleyen (geleneksel yollarla tanınmaz hale getiren) maharetinin altının

Culler bu durumu, Barthes'ın S/Z'de Balzac'in Sarrasine'ini, geleneksel bir metin olarak okunabilir /yazlabilir metin ayrımında olumsuzladığı okunabilir metin kutbuna yerleştirmesini, ancak okunabilir diye küçümsediği bu metnin Barthes'e inanılmaz analizler yapma imkanını sunmasını, S/Z'nin büyük paradoksu olarak değerlendirir. "S/Z'de yatan paradoks, kategorilerinin Balzac'ın somut örneğini oluşturduğu klasik, okunabilir yazını açıkça küçümsemeleri ama çözümlemesinin Balzac tarzı bir kısa romanı çekici ve güçlü bir karmaşıklıktan ötürü desteklemesidir. (...) "Yazılabilir olan bizim değerimizdir" diye ilan eden S/Z, yine de, okunabilir bir öyküyü alır ama ortaya sıkıcı bir öngörülebilirlik koymak yerine çözümleme öyküyü açar, öyküyü kendi kodları ve kendi kültürünün anlamlandırıcı mekanizmaları üzerine akıllıca ve yetkin bir düşünce biçiminde sunar. (Culler, 2008: 99-100) 
Barthes'ın Sarrasine (S/Z) okuması ile Sâmipaşazâde Sezâi’nin Bu Büyük Adam Kimdir? hikâyesinde hermenötik kod sorunu / A. G. Gündoğdu(pp. 248-261)

çizilmesidir (Eagleton, 2011: 150). Ancak diğer taraftan Barthes'ın analizlerinin bu benzersizliği, hermenötik kod düzleminde görüleceği üzere, onun okurlarını birbiriyle benzeyen okuma tecrübelerine yöneltmesinin önünü alamaz.

\section{Hermenötik ile muamma (enigma) kavramlarının çoğul anlam dünyası}

Elbette bu yazının sınırları içinde hermenötik ve muamma kavramlarının çokkatlı anlam dünyası üzerinde uzunca durma imkanına sahip değiliz. Ancak en azından edebî metinlerin yorumlanması söz konusu olduğunda, gerek hermenötiğin gerekse onunla ilişkili olarak muamma (enigma) kavramının hermenötik kod içerisinde kendisine biçilen sınırlarının dışına taşan anlam dünyasına kabaca da olsa temas edebiliriz.

Kod kelimesiyle yan yana gelerek $S / Z$ nin beş okuma düzleminden birisinin adını oluşturan hermenötik kelimesine bakıldığında hermenötik kod adlandırmasının daha ziyade klasik hermenötiğin anlam alanı üzerine inşa edildiği görülür. Oysaki hermenötik klasik kullanımlarının çok ötesine giden önemli bir tarihsel dönüşümün içinden geçmiştir. Buna göre, klasik hermenötik tarihi anlam ve önemini, Schleiermacher ile (onun evrensel hermenötik projesi ile) birlikte başlayan modern hermenötiğin tarihsel süreci içinde gittikçe farklılaşan bir görünüm içinde yeniden kazanmaktadır. $\mathrm{Bu}$ yönüyle klasik hermenötik tarihi Tatar'ın öne çlkardığı üzere "bir bakıma tersinden okunan bir tarihtir.” (Tatar, 2016: 9). Ricoeur, Schleiermacher'in Hermenötiği adlı yazısında bu önemli dönüşüm üzerine odaklanarak, ilk kilisenin zamanından beri Yeni Ahit'in figürlerini Eski Ahit figürleriyle yorumlayıcı bir ilişki içinde yerleştirmeye çalışan bir Hıristiyan hermenötiği varken, kaldı ki Kilise Babaları dönemi hermenötik refleksiyonun açık bir kanıtı iken, Reform sırasında teolojik aksiyom "sola fide" (yalnızca inançla) ve hermenötik aksiyom "sola scriptura"yı (yalnızca yazıyla, kutsal metinle) birbirine bağlayan Protestan Reformu ile bunu kabul etmeyen Karşı Reform arasında süregelen hermenötik bir tartışma söz konusuyken, hermenötik sorunun niçin Schleiermacher ile başlatıldığı üzerinde durur. Verdiği cevap, anlama sorunu denen şeyin temelde onunla birlikte yükselmesidir (Ricoeur, 1977: 181). Anlama sorunu denen şeyin yükselişi ise hermenötiğin dogmatik bir amaca hizmet etmekten uzaklaşarak evrensel bir anlama düzeyine yükselebilmesi anlamına geliyordu. Gadamer, Schleiermacher'ın bu öncüllüğünü şöyle dillendirir: İlk kez Schleiermacher, F. Schlegel'nn etkisiyle, hermenötiği evrensel bir anlama ve açımlama öğretisi haline getirmeyi denemiş ve onu tüm dogmatik vesileci yönlerinden çözmeye gayret etmiştir (Gadamer, 2003: 17). Yine Dilthey'ın hermenötik üzerine düşüncelerini dile getirirken, hermenötiğin evrensel bir tarihsel organon düzeyine yükselmedikçe kendi hakiki varlığını bulamayacağına, bu düzeye yükselebilmesi için de bütün dogmatik sınırlamalardan kurtulması ve özgürleștirilmesi gerektiğine işaret eder (Gadamer, 2009: 247).

Buraya kadar üzerinde durmaya çalıştığımız şey 18. yüzyıla kadar teoloji ve filoloji içerisindeki görünümüyle hermenötiğin, bir şekilde kısmî kalması ve didaktik amaçlara hizmet etmesidir (Gadamer, 2003: 16). Böyle bir ortamda hermenötik refleksiyonun amacı gerek teoloji gerekse filoloji içinde (antik hermenötiğin merkezindeki alegorik yorumlama sorununda görüleceği üzere) sözel ve sıradan anlamın ardında yer alan esas (derin, tinsel) anlamı açığa çıkarma, deşifre etme çabası haline gelir ve bu bir anlamda klasik hermenötiğin anlam dünyasını inşa eder.

Görünen o ki Ricoeur'nün işaret ettiği ve Gadamer'in dile getirdiği üzere hermenötik en başından itibaren birçok farklı refleksiyon düzeyini kapsayan bir terim olur (Gadamer, 2006: 29). Ancak anlama sorunu denen şey, Schleiermacher'ın evrensel hermenötik projesi ile yükselir. Elbette, Schleiermacher

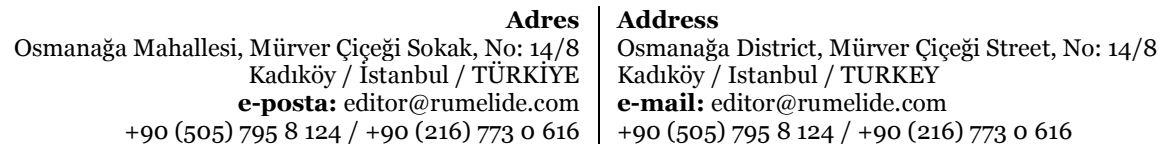


sonrasında da hermenötik, anlama sorunu etrafında çoklu tarihini oluşturmaya devam eder. Dilthey'ın anlamayı hayatın kendisiyle ilişkilendirdiği yaşantı kavramında, Husserl fenomenolojisi ve Ingarden’in fenomenolojik estetik çalışmalarında, Heidegger, Gadamer, Ricoeur ve Derrida gibi isimlerin fenomenolojik kökenli düşünme tarzlarında bu kaynak ruh birbirinden farklı biçimlerde şekillenir. Ama yine de anlama sorununda amacın bir yazarın kendisini anladığından daha iyi anlamak olduğunu öne süren Schleiermacher'ın bu ifadesinin hermenötik probleminin tümünü içerdiğinin söylenmesi onun hermenötiğin dönüşümü içindeki önemini gözler önüne serer. “(...) bu, o zamandan beri tekrarlanagelen bir formüldür ve modern hermenötiğin tarihinin tamamı, bu formülün yorumundaki değişmelerin tarihi olarak okunabilir" (Gadamer, 2009: 267).

Yine hermenötiğin farklı refleksiyon düzeylerinde oluşan bu çoklu tarihi üzerinde dururken, onun ele aldığı konuların oluşturduğu envanterin genişliği üzerinde de birkaç cümle söylemek gerekebilir. Zira hermenötik temelde bir anlama sorunu olduğundan ve anlama sorunu denen şey birçok farklı bağlamda ortaya çıktığından, hermenötik bir kanun metninden bir şiire kadar birçok farklı disiplinde uygulama alanına sahiptir. Tatar'ın vurguladığı gibi günümüzde hermenötik; edebiyat, dil bilimleri, kültürel antropoloji, teoloji, estetik, tarih felsefesi, din bilimleri, uluslararası ilişkiler, hukuk gibi çeşitli sosyal ve siyasi bilimlerden tıp bilimlerine varıncaya kadar çok geniş bir yelpaze içinde etki tarihini sürdürmektedir (Tatar, 2016: 29-30). Bu anlamda hermenötik Bruns'un vurguladığı üzere, "çoklu, katmerli bir tarihe aittir ve bu nedenle, başlayan ve biten ve yol boyunca kavramsal devrimlere maruz kalan tek bir şeye dönüştürülemez" (Bruns, 1992: 213). Görünen o ki, anlama sorununun sinırlarının ne olacağı, nasıl çerçevelenebileceği sorunu, hermenötiği tek bir şeye dönüştürme, tek bir refleksiyon düzeyine yerleştirme hususunda bizleri dikkatli olmaya çağırmakta, onun hakkında belli bir kesinlikte konuşmaktan imtinaya davet etmektedir. Bununla birlikte bir o kadar geçerli olan şey, Gadamer’in dillendirdiği gibi hermenötiğin, bir şeyin anlamı açlk ve net olmadığında gerekli olan bir refleksiyon çabası olduğudur (Gadamer, 2006: 29). Kanaatimizce bunun anlamı, bir şeyin anlamı açık ve net olduğunda hermenötiğin asıl varlığını sergileyemeyeceğidir. Bu anlamda Barthes'ın hermenötik kod düzlemi etrafında ördüğü ikinci önemli kavram olan muammanın, hermenötiğin hakiki varlığını sergilemesini besleyen bir tabiata sahip olduğu söylenebilir. Ancak yine burada asıl önemli olan Barthes'ın tıpkı hermenötik kavramına olduğu gibi muamma (enigma) kavramına da hermenötik kod içinde nasıl bir anlam biçmiş olduğudur. Bu noktada dikkat çeken Barthes'ın, edebî metin okumasına dair bir çoğul oluşturma çabası içine girerken hermenötik kavramını okurun metnin muhtevası üzerine yoğunlaşarak açığa çıkarabileceği bir enigma, çözebileceği oldukça net bir kod olarak sınırlı bir boyutuyla ele almasıdır. Zira hermenötik kod, edebî metnin muhtevasıyla ilgili olarak odağına bir muammanın (enigma) yerleştirildiği, geciktirildiği ve nihayetinde çözümlendiği okuma düzlemi olarak tanımlanır. Oysaki hem hermenötik hem de muamma kavramlarına bu şekilde yaklaşmak edebî metnin çoğulluğunu açığa çıkarmaktan ziyade metnin içine yerleştirilen bir anlamın açı̆̆a çıkarılmasını hatırlatır. Metnin odağına yerleştirilen ancak nihayetinde çözüme ulaşan çok anlamlı muammanın hermenötik kod aracılı̆̆ıyla deşifre edilmesinin, metnin derin, asıl anlamının açığa çıkarıldığı klasik hermenötiğin sahip olduğu refleksiyon düzeyine ilişkin olduğu, klasik hermenötiğin anlam dünyası üzerine inşa edildiği söylenebilir. Burada hermenötik anlama sorunu karşısında hakiki varlı̆̆ını sergilemekten ziyade belli bir amaca hizmet ediyor görünür. Hermenötiğin sahip olduğu çoklu anlamsal tarih, onun çok sınırlı ve hakiki varlığını sergileyemeyeceği sorunlu bir düzey üzerinden yansitılır.

Barthes'in hermenötik kod adlandırması ve anlamlandırmasında benzer bir durumun muammanın kavramsal dünyası üzerinden gerçekleştirildiği görülür. Felsefi düşüncenin oldukça köklü ve önemli kavramları arasında yer alan muammanın hermenötik kod içerisinde kazanmış olduğu anlam, edebî 
Barthes'ın Sarrasine (S/Z) okuması ile Sâmipaşazâde Sezâi’nin Bu Büyük Adam Kimdir? hikâyesinde hermenötik kod sorunu / A. G. Gündoğdu(pp. 248-261)

eserde kat kat açllan ve nihayetinde net, mutlak bir çözüme ulaşacak gizemli bir bilmeceye yahut bilmecelere dairdir. "Sarrasine" ve "Bu Büyük Adam Kimdir?" üzerine yaptı̆̆ımız analizlerde daha açı görülebileceği üzere hermenötik kod içinde edinmiş olduğu anlam nedeniyle muamma (enigma) yerine zaman zaman bilmece sözcüğünün daha fazla ön plana çıkması ve tercih edilen bir kullanım sıklığına ulaşması büyük ölçüde bu durumla ilgilidir. Buna göre hermenötik kod, bilmecenin okurun metin boyunca gördüğü, tanıdığı ve düzenlediği ayrıntılar sayesinde çözümlendiği okuma düzlemidir. Burada hermenötik ve muamma kelimeleri etrafında örülen hermenötik kod ifadesinin metinde ilk elden görülmeyen anlamın (muamma, enigma) açı̆̆a çıkarılmasına, deşifre edilmesine hizmet eden bir refleksiyon düzeyi olarak konumlandırıldığı görülür. Muammaya atfedilen bu anlamsal düzeyin, öne çıkardığı belli bir muammanın ardındaki mutlak anlama ulaşma niyeti bağlamında, Barthes'ın edebî metin etrafında çoğulluk oluşturma amacına uygunluk gösterdiği söylenemez. Zira felsefi düşüncenin başlangıcından itibaren en önemli kavramlarından birisi olmuş muamma (enigma) temelde, çok anlamlılıkla ilişkilidir. Felsefenin Doğuşu adlı çalışmasında bu kavram üzerinde uzunca duran Colli, ancak çok anlamlılığın bir şeyi muamma kılacağına dikkat çeker (Colli, 2007: 41).

$\mathrm{Bu}$ perspektif içinde muammanın deşifre edilmesi değil, çok anlamlılı̆̆ını sürdürebilmesi bir şeyi muamma kılan husustur. Tersten bakıldığında da görülen, edebî metinler etrafında çok anlamlılığı sürdürmek söz konusu olduğunda, onun muamma ile olan ilişkisinin diri tutulmasının önemidir. Edebî metinlerin çok anlamlılığı ile ilgili olarak düşünüldügünde muammanın sadece, edebî metnin muhteva düzleminde kendisini gösteren ve çözülmesi gereken bir bilmece değil, bizatihi edebî metnin okunma sürecine, doğasına ilişkin olduğu da fark edilir. Bu noktada kanaatimizce, sanat eserinin muamma ile ilişkisini net, mutlak bir sonuca ulaştırmaktan ziyade diriltebilmenin ve sürdürebilmenin edebî metnin çoğulluğunu oluşturmaya daha fazla katkı sağlayacağı söylenebilir. Hermenötik kod içerisindeki muamma (enigma) ise, edebî metnin muhtevasında yer alan bir bilmecenin, şifrenin çözülmesi olarak felsefi düşünce içinde yer alan ve çok anlamlılıkla zorunlu bir ilişki halinde olan muammadan (enigma) ziyade, kriptografi (şifreleme) tarihinde yer alan enigmayı hatırlatır. Bilindiği gibi kriptografi tarihinde enigma, gizli mesajların şifrelenmesi ve tekrar çözülmesi amacı ile kullanılan bir şifre makinesidir. En ünlüleri İkinci Dünya Savaşı öncesinde ve savaş sırasında Nazi Almanyasında kullanılan bu makineler Ordu ve Devlet kurumları için özel bir hizmet vermiştir. Hermenötik kod içerisindeki enigmanın da benzer bir şekilde -eşseslisi gibi- gizli mesajların şifrelenmesi ve tekrar çözülmesi amacına hizmet ettiği görülür. Edebî metin adeta bir kriptografi mekanizması konumuna getirilir. Bu durumda ortaya çıkan sorun, edebî metnin öncesinde şifrelenen sonrasında ise çözülebilen bir şey olup olmadığıdır? Edebî bir metin okurun çözebildiği, bu anlamda arkasında, gerisinde bırakabildiği bir şey midir? Şifrelenen gizem çözüldüğünde rahatlanılan, okurlarına sormayı sürdüreceği bir sorusu kalmayan bir mekanizma mıdır? Temelde burada edebî metindeki muammayı çözmenin mi yoksa edebî metnin muamma ile olan ilişkisini diri tutmanın mı ontolojik bir okuma tecrübesine daha ait olduğu sorunu baş gösterir. Ve nihayetinde hangisinin dünyayla kurduğumuz ilişkiyle daha uyum içinde olduğu. Kanaatimizce, okurun tarihselliği ve edebî metnin belirlenemezliği, tüketilemezliği, Barthes'ın ifadeleriyle kıyısız, sınırsızlı̆ğ göz önünde bulundurulduğunda edebî metnin muammasının çözülmesinden ziyade sürdürülmesinin onun etrafında bir çoğulluk oluşturmaya katkı sağlayabileceği görülür. Edebî metnin muammasının çözümü kendisiyle birlikte kendisiyle ilişkili bazı kelimelerin de okuma sürecinde göz ardı edilmesi anlamına gelir. Düşünce tarihinde zaman zaman muammaya ilişkin anlamında kullanılan "diyalektik" (Colli, 2007:62), "sorgulama, aporia, araştırma ve yanıtı belirsiz soru” (Colli, 2007:65), gibi terimler bunlar arasındadır. Bilindiği gibi bu kelimelerin bir kaynaşması olarak görülebilecek soru-cevap diyalektiği Gadamer'in felsefi hermenötiğinde, yorumlama faaliyeti alanında hayati bir öneme sahiptir. Dolayısıyla, diyalektik, aporia, sorgulama gibi kelimelerle sürekli ilişki halinde olan muamma perspektifinin, felsefi

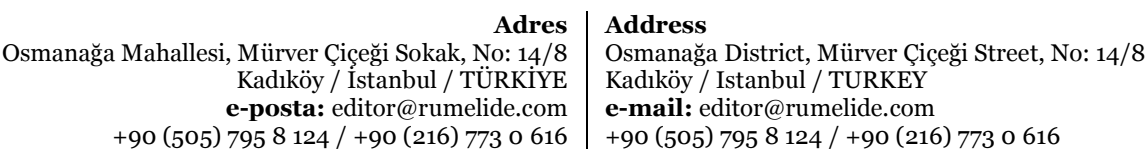


hermenötiğin dünyasıyla daha uyumlu olduğu söylenebilecektir. Bu unsurların okuma sürecinin dışına itilmesinin ayrıca, okur ile metin arasındaki (Barthes'ın adlandırmasıyla söyleyecek olursak) “yazılabilir metin” (Barthes, 2016: 16) anlayışının devinimini durağanlaştıracağını da eklememiz gerekir. ${ }^{6}$ Dahası aynı perspektif içinde, muammanın sürekliliği, edebî metnin muammasında olduğu gibi, her şeyi tam olarak kuşatamayacağımızın, insan olmanın sınırlılığının, ölümlülüğünün, sorularla yaşamak durumunda kalmışlığımızın da bir ifadesi olarak yaşadığımız hayat ile daha uyumlu bir ilişki sergiler. Burada muammanın ortaya çıkış hikayesinin Tanrıların insanlara meydan okumasıyla ilişkili olduğu hatırlanabilir. "Sfenks, insanın üç çağı üzerine bir bilmece sorarak, Thebaililer'e Tanrının ölümcül meydan okumasını sunar” (Colli, 2007: 42).

Geldiğimiz noktada muammanın kökenini oluşturan anlatılarla ilgili olarak dikkat çekmek istediğimiz son husus, önce Tanrllardan insanlara yönelen, daha sonrasında kahinler arasında insani bir tartışmacılığa dönüşen muammaların tuzağına düşmek motifi ile ilgilidir. Bilindiği gibi en ünlü muamma anlatılarında, muammaya verilen doğru yahut yanlış cevap karşısında muammayı soran yahut kendisine muamma yöneltilen kişinin bir şekilde cezalandırılışı söz konusudur. Sfenks’in muammalarında durum böyledir. "Sadece muammayı çözebilen kişi kendisini ve kentini kurtarabilecektir... Ölüm kalım savaşı verilir; muammayı çözemeyen Sfenks tarafından parçalanacak ya da boğulacak, çözense -sadece Oidipus onu yener- Sfenks'i uçuruma yollayacaktır" (Colli, 2007: 42). Yine iki kahinin muamma için çarpıştığı Kalkhas'ın Mopsos'a sorduğu soru neticesinde Mopsos'un doğru cevabı üzerine Kalkhas'ı ölümün uykusu sarar (Colli, 2007: 43). Çözemediği muamma karşısında ümitsizliğe kapılarak oracıkta can veren Homeros'un hikayesi de benzer bir akıbeti içerir. "Homeros, kıyıya yaklaşan balıkçılara, bir şey tutup tutmadıklarını sormuş. Onlar da hiçbir şey tutamadıkları gibi üstüne bir de bitlendikleri için yakaladıkları bitleri öldürüp attıklarını, yakayamadıklarını da üzerlerinde getirdikleri olgusunu bir muamma ile anıştırarak şöyle demişler(dir): "Aldıklarımızı bıraktık, almadıklarımızı da getirdik" (Colli, 2007: 51). Her üç ünlü muamma anlatısında da, muammanın tuzağına düşen kişi ya parçalanır ya boğulur, ya ölümün uykusu etrafını sarar ya da oracıkta can verir. Colli, bu cezalandırmaya ilişkin olarak Yunan dünyasınından günümüz dünyasına geldiğimizde, muammanın sarp arka planının insani tartışmacllıkla yer değiştirerek hafiflediğini söyler ve ekler: "Diyalektik soruya yanıt veren kişi trajik bir kayboluşta bulmuyor artık kendini. Yenilmiş olsa da, Homeros'un başına geldiği gibi, ölmeyecek artık” (2007: 66). Colli’nin bu iddiasına rağmen, söz konusu edebî metinlerin okunması olduğunda okurun cezasının hafiflediğini söyleyebilmek halen mümkün değildir. Muammayı çözerek net bir çözüme ulaştığını düşünen okur, müebbet olarak ağırlaştırılmış bir cezaya çarptırılır: metinsizlik cezasına. Tartışmacılı̆̆ın toprağından doğan diyalektiğin son bulduğu, sorulacak sorular ve verilecek cevapların kalmadığı, her şeyin mutlak bir çözüme ulaştığı noktada, okurun artık çoktan gerisinde bıraktığı bir şey haline dönüşmektedir çünkü metin. Çözülerek geride bırakılan edebî metnin şeyleşmesi anlamında edebî metin ve muamma ilişkisine yönelik, "metnin muammasını çözebildiniz mi? şeklinde sorulacak soruya verilebilecek cevaplardan birisi, Homeros'un bit muammasını anıştırarak söyleyecek olursak "çözdüklerimizi (geride) bıraktık, çözemediklerimizi de getirdik" halini alacaktır.

Hermenötik kod içerisinde yer aldığı şekliyle muammanın tuzağına düşmenin bir başka boyutunu da, bu kodun edebî metindeki tüm gizem ve gerilimi yönetip, neyin gizem olarak sayılacağını tamamen belirleyebileceğine yönelik inancın oluşturduğu söylenebilir. Söz konusu edebî bir metnin okunma

Söz konusu bu ortaklık aralarındaki yol ayrımlarına rağmen Barthes ve Gadamer’in metinleri anlama sorunu karşısında hem fikir oldukları birçok konu olduğuna da işaret eder. Gadamer ve Barthes arasındaki karşıtlıklar ve benzerlikler üzerine odaklanan önemli bir çalıșma için bakınız. David Couzens Hoy (1982). “"History or Literature?”” Gadamer contra Barthes", The Critical Circle, Literature, History and Philosophical Hermeneutics. Berkeley and Los Angeles: University of California Press, 141-146. 
tecrübesi olduğunda okur için gerçekte neyin gizem oluşturabileceğine karar verebilecek ve bunu bütün okurlar nezdinde geçerli kılabilecek bir yetki söz konusu değildir. Daha önce de değinildiği üzere, Barthes hermenötik kodun gerçeğin sesini (Barthes, 2016: 30) seslettiğini dile getirir, lakin edebî metin, edebî bir metin olmaklığını, hakikatinin sesini okurlarının dünyasına ne zaman ve ne şekilde sesleteceğinin belirsizliği ve öngörülemezliği üzerinden kazanır.

\section{Sonuç}

En büyük amacı ve iddiası edebî metinlerin çoğulluğunu ortaya çıkarmak olan $S / Z$ adlı çalışmasında Barthes'in, -hermenötik kod düzleminde ele almaya çalıştığımız üzere-, bunu tesis etmek için oluşturduğu teknik kavramlarda tamamen aynı istikamette ilerlediği söylenemez. Edebî metinlerin çoğulluğunu ortaya çıkarırken bunu mümkün kılmak için oluşturulan kavramların tarihsel dönüşümlere uğramış çoğul anlam dünyasını göz önünde bulundurmak da önemlidir. Hermenötik kod içinde, hermenötik ve muamma (enigma) kavramlarına biçilen anlam dünyasına bakıldığında, bunun onların çoğulluğunu ortaya çıkarma amacına yönelik olmaktan ziyade metnin derin yapısını, arkasındaki anlamı ortaya çıkarmaya hizmet ettiği görülür. Bu anlamda $S / Z$, Barthes'ın gitmek istemeyeceği başka noktalara da uzanarak eksik kalmak durumunda kalan bir çoğulluk oluşturma iddiasını taşır.

Hermenötik kodun edebî metin okumalarımızı nasıl etkilediği ve yönlendirdiği hususunda, Barthes'ın $S / Z$ okuması ile Sâmipaşazâde Sezâi'nin Bu Büyük Adam Kimdir? adlı eseri arasında yapılan karşlaştırmaya bakıldığında ise; bu kodun bir taraftan okurların yorum alanını genişleten çeşitli analizler yapmasına imkan sunduğu görüldü. Bu analizleri Sarrasine'de papanın otoritesinin tiyatro ve mûsikî tarihine yansıması oluşturur. Bu Büyük Adam Kimdir?'de Batılılaşmayı dış görünüş olarak değerlendiren, gerçekliği yüzeyde arayan Tanzimat dönemi algılama sorunu ve Tanzimat sonrası yükselen bilimselci düşünce içinde, insanın yüz ve vücut yapısı ile karakteri arasında bir bağ kuran ilm-i klyafet eleştirisi kendisini gösterir. Diğer taraftan hermenötik kod etrafında gerçekleştirilen okumaların, okurlarını birbiriyle benzeyen okuma tecrübelerine yönlendirdiği saptandı. Bu benzer tecrübeler içinde okura yüklenen rol; okurun metinle ilişkisinin onun muhtevası üzerine yoğunlaşarak ortaya konan ve çözülmesi gereken bir muamma ile ilgilenmek, bu gizemi çözecek ayrıntıları görmek, tanımak ve düzenlemek durumunda kalmasıdır. Bu durumsa okuru, kız-erkek, câhil-bilgin gibi ikili karşıtlıklar şeklinde düşünmeye sevk eder ve okuma sürecini şekillendirir.

\section{Kaynakça}

Barthes, R. (1977). Work to Text. Image Music Text. Stephen Heath (Trans.). London: Fontana Press, 155-164.

Barthes, R. (2006). S $\mid Z$. Sündüz Öztürk Kasar (Çev.). İstanbul: YKY. (Özgün eser ilk kez 1970 yllında yayımlanmıştır).

Bruns, G. L. (1992). Hermeneutics Ancient and Modern. New Haven and London: Yale University Press.

Chatman, S. (2008). Öykü ve Söylem Filmde ve Kurmacada Anlatı Yapısı. Özgür Yaren (Çev.). Ankara: De Ki.

Colli, G. (2007). Felsefenin Doğuşu. Fisun Demir (Çev.). Ankara: Dost.

Culler, J. (2008). Barthes, Hakan Gür (Çev.). Ankara: Dost.

Eagleton, T. (2011). Edebiyat Kuramı: Giriş. Tuncay Birkan (Çev.). İstanbul: Ayrıntı.

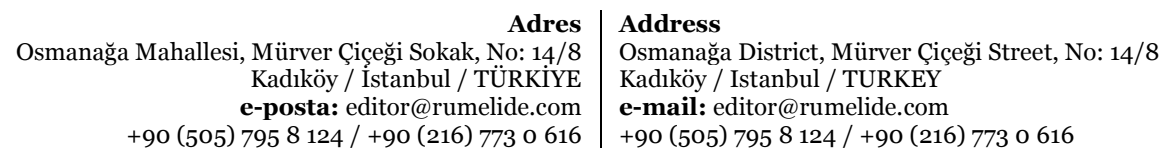


Gadamer, H. G. (2006) Classical and Philosophical Hermeneutics. Theory, Culture \& Society. (SAGE, London, Thousand Oaks and New Delhi), 23(1), 29-56. DOI: 10.1177/0263276406063228.

Gadamer, H. G. (2009). Hakikat ve Yöntem. Hüsamettin Arslan ve İsmail Yavuzcan (Çev.ler). Cilt I, İstanbul: Paradigma.

Gadamer, H. G. (2003). Hermeneutik. Hermeneutik Üzerine Yazılar. Doğan Özlem (Der. ve Çev.). İstanbul: İnkılap.

Hoy, D. C. (1982). History or Literature? Gadamer contra Barthes. The Critical Circle, Literature, History and Philosophical Hermeneutics. Berkeley and Los Angeles: University of California Press, 141-146.

Palmer, R. E. (1983). Postmodern Hermeneutics and the Act of Reading. Notre Dame English Journal. $15(3), 55^{-84}$.

Ricoeur, P. (1977). Schleiermacher's Hermeneutics. The Monist. Philosophy and Religion in the 19th Century, Oxford University Press, 60 (2), 181-197.

Rosenthal, P. (1975). Deciphering S/Z. College English. National Council of Teachers of English, 37 (2), 125-144.

Sâmipaşazâde Sezâi (2016). Küçük Şeyler. Kemal Bek (Haz.). İstanbul: Özgür Yay. (Özgün eser ilk kez 1892 yılında yayımlanmıştır).

Tatar, B. (2016). 3 Derste Hermenötik. İstanbul: Vadi. 